Jurnal IImiah Iqra'

2541-2108 [Online] 1693-5705 [Print]

Tersedia online di: http://journal.iain-manado.ac.id/index.php/JII

\title{
Dinamika Politik Pendidikan Islam Di Indonesia; Studi Kebijakan Pendidikan Islam Pada Masa Pra-Kemerdekaan Hingga Reformasi.
}

\author{
Muhammad Sholeh Hoddin \\ SMA Nazhatut Thullab Sampang \\ saladin.19800918@gmail.com
}

\begin{abstract}
Abstrak
Catatan sejarah membuktikan bahwa kebijakan pendidikan Islam, khususnya di Indonesia mengalami pasang surut, tergantung siapa yang mempunyai peran dalam menentukan kebijakan tersebut. Kajian yang bersifat literistik ini berupaya menyajikan dinamika politik pendidikan Islam di Indonesia, mulai masa praKemerdekaan sampai dengan masa Reformasi. Penelitian ini menghasilkan empat buah potret relasi politik dan pendidikan Islam di Indonesia, pertama, bahwa pada masa pra-kemerdekan, kebijakan yang dikeluarkan pemeritah Belanda dan Jepang bersifat diskriminasi; kedua, ada upaya pembenahan terhadap kebijakan pendidikan Islam yang dilakukan oleh pemerintah Orde Lama, namun suhu politik yang tidak kondusif, di antaranya adanya pertentangan antara kelompok nasionalis, sekulerkomunis, dan Islam, berakibat tidak optimalnya implementasi kebijakan tersebut; Ketiga, melalui Tap MPRS No.27, pasal 1 tanggal 5 Juli 1966, pemerintah Orde Baru menetapkan bahwa "Agama, pendidikan dan kebudayaan adalah unsur mutlak dalam Nation and Character Building" , namun masih mengalami hambatan dengan adanya kebijakan sentralistik dalam pelaksanaan kurikulum pendidikan; Keempat, terbitnya Undang-Undang nomor 20 tahun 2003 tentang Sistem Peendidikan Nasional, khususnya pada pasal 12 ayat 1 (a) pada masa Reformasi merupakan perkembangan yang sangat positif bagi pendidikan Islam, walaupun masih menimbulkan pro dan kontra; dan dengan terbitnya Permendikbud No. 64 Tahun 2013 Tentang Standar Isi Pendidikan Dasar dan Menengah menjadikan UndangUndang nomor 20 tahun 2003 lebih bermakna dan aplikatif.
\end{abstract}

Kata kunci: Politik; Kebijakan; Pendidikan 


\begin{abstract}
Historical records prove that Islamic education policy, especially in Indonesia experiences ups and downs, depending on who has a role in determining the policy. This literary study seeks to present the political dynamics of Islamic education in Indonesia, from pre-Independence to the Reformation. This study produced four portraits of political relations and Islamic education in Indonesia, first, that, in the pre-independence period, the policies issued by the Dutch and Japanese governments were discriminatory; secondly, there are efforts to reform Islamic education policies carried out by the Old Order government, but the political climate is not conducive, including conflicts between nationalist, secular-communist, and Islamic groups, which results in suboptimal implementation of these policies; Third, through MPRS Tap No.27, article 1 dated July 5, 1966, the New Order government determined that "Religion, education and culture are absolute elements in the Nation and Character Building", but still faced obstacles with the existence of a centralized policy in the implementation of the education curriculum; Fourth, the issuance of UUSPN number 20 of 2003, especially in article 12 paragraph 1 (a) during the Reformation was a very positive development for Islamic education, although it still raises the pros and cons, and with the publication of Permen Dikbud No. 64 of 2013 concerning Content Standards Primary and Secondary Education makes UUSPN number 20 of 2003 more meaningful and applicable.
\end{abstract}

Keywords: Political; Policy; Education

\title{
Pendahuluan
}

Sejak manusia diciptakan pertama kali, ia tidak lepas dengan pendidikan. Untuk itu, pendidikan merupakan sesuatu yang mesti ada dalam hidup dan kehidupan dan ia adalah way of life, suatu jalan hidup manusia. Ada asumsi life is education and eduction is life, dalam arti pendidikan merupakan persoalan hidup dan kehidupan serta seluruh proses hidup dan kehidupan manusia adalah proses pendidikan (Ellong \& Pawero, 2018). Maka pendidikan Islam pada dasarnya hendak mengembangkan pandangan hidup Islami yang diharapkan tercermin dalam sikap hidup dan keterampilan hidup orang Islam. Sebagaimana dalam ruang lingkup pendidikan Islam yang meliputi; Hubungan manusia dengan Allah, hubungan manusia dengan sesama manusia, hubungan manusia dengan dirinya sendiri, serta hubungan manusia dengan lingkunyan (A. M. Pawero, 2017)

Sejarah mencatat bahwa pendidikan Islam di Indonesia telah berjalan sesuai dengan masuknya Islam ke Indonesia yang menurut teori Makkah dan teori Maritim terjadi pada abad ke-1 H atau abad ke-7 M (Suryanegara, 2012). Da'wah Islamiyah di Indonesia dilaksanakan dengan berbagai metode, mulai dari pernikahan, 
perdagangan, budaya, pengobatan maupun pendidikan. Bersamaan dengan proses penyebaran itulah terjadi transformasi nilai-nilai pendidikan Islam (Rifai, 2011).

Pendidikan Islam yang berkembang dari awal masuknya ke Indonesia, telah membawa perubahan besar bagi bangsa Indonesia. Mulai dari bentuknya (yang sederhana seperti langgar/surau, mesjid, dan pesantren sampai dengan sistem klasikal seperti madrasah merupakan sarana pendidikan Islam di Indonesia yang selalu mengalami dinamika kebijakan dari lingkungan pemerintah yang membawahinya (A. M. D. Pawero \& Dkk, 2019a).

Sebagai bangsa yang besar, Indonesia memiliki sejarah panjang tentang perjalanan kebijakan pendidikan Islam, mulai dari masa pra kemerdekaan sampai dengan masa reformasi. Dengan strategi penataan kurikulum pendidikan Islam, diharapkan mampu menjawab kebutuhan sumber daya manusia dalam mendorong pertumbuhan nasional dan daerah (Ellong \& Pawero, 2018).

Pada masa pra kemerdekaan, kebijakan pemerintah Belanda atau Jepang terhadap pendidikan Islam sangat bersifat diskriminatif. Pemberlakuan kebijakan ini tidak lepas dari kepentingan mereka sebagai bangsa penjajah yang merupakan bagian dari politik kolonial. Diskriminasi terhadap pendidikan Islam juga tidak lepas dari kekhawatiran penjajah terhadap umat Islam yang merupakan penduduk mayoritas di Indonesia. Sebagaimana dapat dilihat dalam sejarah, umat Islam yang sangat menetang penjajahan Belanda ataupun Jepang.

Berakhirnya masa penjajahan Belanda dan Jepang, menjadi babak baru kebijakan pendidikan Islam dalam sejarah Bangsa Indonesia yang merdeka. Kemerdekaan Bangsa Indonesia yang jatuh pada tanggal 17 Agustus 1945 merupakan awal dimulainya pemerintahan yang dipimpin oleh Ir. Soekarno. Pemerintahan yang dikenal dengan istilah orde lama ini menjadikan Pancasila dan UUD 1945 sebagai dasar dalam menyusun sistem pendidikan nasional termasuk di dalamnya adalah kebijakan pendidikan Islam (Ismail, 2016).

Sebagai bangsa yang mayoritas penduduknya beragama Islam, wajar jika pemerintah orde lama memberikan perhatian yang serius terhadap pendidikan Islam baik di sekolah negeri ataupun swasta. Namun dengan adanya kondisi negara yang masih belum stabil akibat tarik ulur kepentingan antara petinggi negara yang berbeda haluan, menyebabkan terkendalanya implementasi kebijakan pendidikan Islam. 
Orde baru merupakan kelanjutan pemerintahan orde lama yang berakhir pada tahun 1966. Pada pemerintahan yang dipimpin oleh Soeharto, sistem pendidikan nasional, termasuk sistem pendidikan Islam bertujuan untuk membangun sumber daya manusia Indonesia, namun pada tarap implementasinya, kebijakan tersebut bersifat sentralistik.

Pendidikan Islam mendapatkan angin segar ketika masa reformasi menggantikan 32 tahun Presiden Soeharto memimpin bangsa Indonesia. Masa reformasi membuka belenggu demokrasi. Hal ini ditandai dengan sistem pendidikan yang awalnya berada di bawah kendali pemerintah pusat (sentralisasi), kemudian diubah kebijakan pendidikan dengan kebijakan desentralisasi sistem pendidikan, termasuk di dalamnya pendidikan Islam.

Kebijakan pemerintah terhadap pendidikan tidak lepas dari kondisi dan situasi politik suatu negara yang dilakukan oleh kekuatan sosial yang ingin mengedalikan pemerintahan tersebut. Sebenarnya, kajian politik pendidikan terkonsentrasi pada peranan pemerintah dalam bidang pendidikan, sehingga dapat menjelaskan asumsi dan maksud dari berbagai strategi perubahan pendidikan dalam suatu masyarakat secara lebih baik. Kajian politik pendidikan dapat memberikan pemahaman yang lebih baik tentang kaitan antara berbagai kebutuhan politik negara dengan isu-isu praktis sehari hari di lingkungan lembaga pendidikan.

\section{Kajian Teori}

\section{Politik Pendidikan Islam}

1. Definisi Politik

Secara etimologi, kata politik berakar dari bahasa Inggris politic adalah sinonim dari kata wise dan sensible yang berarti tindakan, bijaksana, kebijaksanaan atau kebijakan (Oxford, 2011). Sedangkan dalam perspektif terminologi, para tokoh berbeda pendapat. Sebagaimana menurut Roger F. Soltou, yang dikutip oleh Budihardjo, ilmu politik adalah ilmu yang mempelajari negara, tujuan-tujuan negara, dan lembaga-lembaga yang akan melaksanakan tujuan-tujuan tersebut serta hubungan antara negara dengan warganya dan dengan negara lainnya. J. Barents mengatakan bahwa ilmu politik adalah ilmu yang mengamati kehidupan negara yang merupakan bagian dari kehidupan masyarakat (Budihardjo, 2001). 
Sementara dalam Kamus Besar Bahasa Indonesia yang dikeluarkan oleh Departemen Pendidikan dan Kebudayaan, menyatakan bahwa definisi politik adalah pengetahuan tentang ketatanegaraan atau kenegaraan atau semua urusan dan tindakan mengenai pemerintahan negara atau terhadap negara lain, atau kebijakan cara bertindak dalam menghadapi atau menangani masalah (Tim Redaksi, 2011).

Dari beberapa definisi di atas dapat ditarik kesimpulan bahwa politik adalah suatu kebijakan yang ditetapkan oleh pemerintah yang merupakan kewenangan penguasa negara tentang hal-hal yang terkait dengan kepentingan negara tersebut dengan masyarakatnya atau dengan negara lain dengan memiliki tujuan untuk memperoleh apa yang dicita-citakan.

\section{Definisi Pendidikan Islam}

Ada tiga term dalam bahasa Arab yang menjadi padanan pendidikan Islam yaitu ta'lim, ta'dib, dan tarbiyah. Pendidikan disebut dengan ta'lim yang berasal dari kata 'allama berkonotasi pembelajaran yaitu semacam proses transfer ilmu pengetahuan. Dalam kaitan pendidikan, ta'lim dipahami sebagai proses bimbingan yang ditekankan pada aspek peningkatan kognisi peserta didik (Jalaluddin, 2004). Istilah ta'lim dalam hal ini memberikan tendensi pada proses interaksi edukatif dalam rangka peraihan tujuan-tujuan yang telah ditentukan.

Istilah yang kedua yaitu ta'dib yang berasal dari kata addaba memiliki konotasi sebuah proses pembinaan yang lebih menekankan pada perbaikan mental manusia yang erat hubungannya dengan masalah moral dan lebih berorientasi pada pengembangan dan peningkatan martabat manusia.

Sedangkan tarbiyah yang berasal dari kata robbaa, pada hakikatnya merujuk kepada Allah selaku Murabby (pendidik) sekalian alam. Kata Rabb (Tuhan) dan Murabby (pendidik) berasal dari akar kata seperti termuat dalam Q.S. Al-Isra': 24. Istilah ini dapat dipahami sebagai sebuah proses pendidikan yang dilakukan dengan sadar dan terprogram, teratur, sistematis, penuh petimbangan, dan terarah pada tujuan (Muhmidayeli, 2011).

Adapun definisi pendidikan Islam, para tokoh berbeda pendapat sebagaimana yang dikutip oleh Muhmidayeli, menurut Omar Mohammad al-Toumy al-Syaibani adalah sebuah usaha untuk mengubah perilaku setiap individu dalam kehidupan pribadinya atau kehidupan masyarakat bahkan dalam kehidupan alam sekitarnya (Muhmidayeli, 2011). 
Sedangkan menurut Ahmad D Marimba, pendidikan Islam adalah bimbingan jasmani maupun rohani berdasarkan hukum-hukum agama Islam menuju terbentuknya kepribadian utama menurut ukuran-ukuran Islam (Marimba, 2009). Senada dengan Marimba, Achmadi mendefinisikan pendidikan Islam adalah segala usaha untuk memelihara dan mengembangkan fitrah manusia serta sumber daya insan yang berada pada subjek didik menuju terbentuknya manusia seutuhnya (insan kamil) sesuai dengan norma Islam atau dengan istilah lain yaitu terbentuknya kepribadian muslim (Achmadi, 2002).

Dari beberapa definisi di atas dapat disimpulkan bahwa pendidikan Islam adalah usaha sadar yang dilakukan oleh pendidik untuk melakukan transformasi pengetahuan (aspek kognitif), membentuk perilaku yang baik pada peserta didik (aspek afektif) serta dapat mengimplementasikan dalam kehidupannya (aspek psikomotorik) yang berakhir pada terbentuknya individu yang sempurna (insan kamil).

\section{Definisi Politik Pendidikan Islam}

Suatu negara dikatakan maju adalah negara yang memiliki pendidikan yang baik. Sebaliknya, negara itu dikatakan negara tertinggal apabila pendidikan masyarakat di negara tersebut sangat rendah. Maka dari itu, pendidikan dan negara sebagai organisasi politik merupakan dua elemen yang tidak bisa dipisahkan. Sebagai pemegang kebijakan politik, pemerintah memiliki peranan besar dalam mengembangkan dan memperbaiki kualitas pendidikan. Pergolakan politik, artinya turun-naiknya iklim politik di suatu negara akan menciptakan kondisi pendidikan di negara tersebut.

Pendidikan dan politik sering dilihat sebagai bagian-bagian yang terpisah, yang satu sama lain tidak memiliki hubungan apa-apa. Padahal, keduanya bahu membahu dalam proses pembentukan karakteristik masyarakat di suatu negara. Lebih dari itu, keduanya saling menunjang dan saling mengisi lembaga-lembaga dan proses pendidikan berperan penting dalam membentuk perilaku politik masyarakat di negara tersebut. Ada hubungan erat dan dinamis antara pendidikan dan politik disetiap negara. Hubungan tersebut adalah realitas empiris yang telah terjadi sejak awal perkembangan peradaban manusia dan menjadi perhatian para ilmuan (Sirozi, 2010).

Pendidikan sering dijadikan media dan wadah untuk menanamkan ideologi negara atau tulang yang menopang kerangka politik. Di negara-negara Barat kajian 
tentang hubungan antara pendidikan dan politk dimulai oleh Plato dalam bukunya Republic yang membahas hubungan antara ideologi dan institusi negara dengan tujuan dan metode pendidikan.

Plato mendemonstrasikan dalam buku tersebut bahwa dalam budaya Helenik, sekolah adalah salah satu aspek kehidupan yang terkait dengan lembagalembaga politik. Plato menggambarkan adanya hubungan dinamis antara aktivitas kependidikan dan aktivitas politik. Keduanya seakan dua sisi dari satu koin, tidak mungkin terpisahkan. Analisis Plato tersebut telah meletakkan fundamental bagi kajian hubungan politik dan pendidikan di kalangan ilmuwan generasi berikutnya.

Sjalabi menyatakan bahwa Islam sebagai bagian dari sejarah telah mencatat peran politik khalifah dan sultan dalam mengembangkan pendidikan terlihat sangat jelas. Salah satu contoh, Khalifah Al-Ma'mun dalam memberikan kebijakan bagi rakyatnya untuk mengembangkan ilmu pengetahuan. Sehingga pada masa ini dikenal sebagai awal dari kebangkitan umat Islam dalam keilmuan. Namun di sisi lain ada kebijakannya yang timpang, karena memberlakukan penyelidikan (mihnah) bagi ulama yang tidak mengakui kemakhlukan al-Qur'an yang menjadi keyakinan negara pada waktu itu (Sirozi, 2010). Begitu juga dengan apa yang telah dilakukan oleh Nizam al-Mulk, salah satu wazir Bani Saljuk. la sangat berjasa dalam mempopulerkan pendidikan Islam melalui sistem klasikal yaitu madrasah. Karena kebijakannyalah madrasah menjadi prototype awal pembangunan lembaga pendidikan tinggi dalam Islam .

Eratnya hubungan antara politik dan pendidikan dalam sejarah Islam, menimbulkan analisis terhadap kasus madrasah Nizamiyah, sebagimana yang dikutip oleh Sirozi dari Rasyid, bahwa politik dalam Islam sama-sama memiliki urgensitas yang tinggi dengan pendidikan (Sirozi, 2010). Tanpa adanya otoritas politik, syari'at Islam sulit, bahkan mustahil bisa ditegakkan. Kekuasaan sebagai sarana dalam mempertahan syari'at Islam. Sedangkan pendidikan bergerak sebagai upaya penyadaran terhadap umat dalam menjalankan syari'at. Tanpa pendidikan umat tidak akan famam terhadap syari'ah. Jika politik (kekuasaan) berfungsi sebagai pengayom dari atas, maka pendidikan akan selalu berbenah diri melalui arus bawah.

Dari adanya pertautan yang erat antara politik penguasa dan pendidikan, maka ada beberapa definisi politik pendidikan yang bisa dipaparkan; di antaranya menurut Lee C. Deighton yang dikutip oleh Bakri adalah segala kebijakan pemerintah suatu negara dalam bidang pendidikan yang berupa undang-undang 
atau peraturan pemerintah untuk menyelenggarakan pendidikan demi tercapainya tujuan negara (Bakri, 2010). Sedangkan menurut Kimbrough dalam Sirozi, politik pendidikan adalah proses pembuatan keputusan-keputusan penting dan mendasar dalam bidang pendidikan di tingkat lokal maupun nasional (Sirozi, 2010).

Dari paparan di atas bisa disimpulkan bahwa politik pendidikan Islam adalah seluruh kebijakan yang tetapkan oleh penguasa dari suatu pemerintahan yang terkait dengan keberlangsungan proses pendidikan Islam, di mana ia sebagai bagian dari sistem pendidikan nasional di negara tersebut. Ada kalanya kebijakan itu memiliki orientasi untuk mempertahankan atau memperkokoh otoritas penguasa, atau ideologi yang dijadikan dasar pijakan oleh negara tersebut.

\section{Politik Pendidikan Islam Di Indonesia}

Perkembangan pendidikan Islam di Indonesia tidak lepas dari peran politik penguasa. Sebagai bagian dari sistem pendidikan Nasional, pendidikan Islam menjadikan pancasila, undang-undang, keputusan MPR atau yang lainnya, sebagai dasar pelaksanaannya. Dalam kajian ini, penulis membatasi pada historis perkembangan pendidikan Islam di Indonesia pada empat periode yaitu masa prakemerdekaan, masa orde lama, masa orde baru, dan masa reformasi

1. Perkembangan pendidikan Islam pada masa pra-kemerdekaan

Sebagaimana yang kita ketahui bersama bahwa, perkembangan pendidikan Islam di Indonesia bersamaan dengan masuknya Islam itu sendiri ke Nusantara. Hal itu menunjukkan bahwa jauh sebelum Belanda menjajah negeri ini, pendidikan Islam telah mengalami perkembangan yang massif. Kedatangan Belanda sebagai bangsa penjajah merubah iklim pendidikan Islam, di mana kebijakan politik, termasuk kebijakan pendidikan untuk pribumi khususnya pendidikan Islam mengalami diskriminasi. Pendidikan pada masa pra-kemerdekaan yang dipengaruhi kolonialisme menjadikan sebagian anak bangsa didik untuk mengabdi kepada pemerintah penjajah. Konsep ideal pendidikan kolonialis adalah pendidikan yang mampu mencetak para pekerja yang dapat dipekerjakan oleh penjajah (Daeng Pawero, 2018).

Kebijakan yang diberlakukan oleh pemerintah Belanda yang bersifat diskriminasi sebenarnya merupakan bentuk ketakutan mereka terhadap kebangkitan militansi umat Islam yang terpelajar yang berasal dari madrasah atau pun pesantren. Karena itu, pada tahun 1982, pemerintah Belanda menerbitkan 
peraturan yang sangat ketat bahwa orang-orang yang memberikan pengajaran atau pengajian agama Islam harus mendapatkan ijin dari pemerintah Belanda. Dilanjutkan pada tahun 1925 dikeluarkan peraturan tentang pendidikan Islam, di mana seorang kiai boleh memberikan pelajaran mengaji, apabila mendapatkan rekomendasi atau persetujuan pemerintah Belanda (Nata \& Dkk, 2004). Di sisi lain, pesantren merupakan wahana penggemblengan rakyat serta pembentukan mental populisme kebangsaan. Berbicara tentang pesantren, khususnya jika dikaitkan dengan era modern seperti sekarang ini, bukan sekedar membahas sistem pendidikan. Berbicara tentang pesantren, lebih dari itu adalah juga berbicara tentang arah, tujuan dan desain seperti apakah bangsa ini dibuat untuk masa yang akan datang (A. M. D. Pawero \& Dkk, 2019a)

Selain kebijakan di atas, pemerintah Belanda juga memberlakukan Ordonansi Sekolah Liar (Wild School Ordonatie). Peraturan yang diterbitkan pada tahun 1932 ini bertujuan untuk memberantas atau menutup madrasah atau sekolah yang tidak mendapatkan ijin dari pihak pemerintah Belanda. Ordonansi Sekolah ini tentu manjadi faktor penghambat perkembangan pendidikan Islam karena kurang tertibnya pengelolaan dan penyelenggaraan pendidikan Islam pada saat itu (Nata, 2001).

Pasca terusirnya Belanda dari bumi Indonesia oleh Jepang pada tahun 1942, sebagai penguasa baru bangsa ini, Jepang mengeluarkan kebijakan pendidikan Islam yang pada awalnya seakan-akan berpihak terhadap umat Islam, namun sebenarnya mempunyai kepentingan agar umat Islam berpihak kepada Jepang dalam perang Dunia II. Di antara kebijakan yang dikeluarkan adalah: (1) memberikan bantuan dana bagi sekolah dan madrasah; (2) mengangkat kalangan kyai, seperti, KH. Hasyim Asy'ari untuk menduduki di Kantor Urusan Agama. Di antara tugas kantor ini adalah mengorganisir pertemuan dan pembinaan guru-guru agama. Dengan alasan pertemuan dan pembinaan inilah pendidikan Islam-pesantren dan madrasah—tetap dapat dipantau dan dikontrol; (3) diizinkanya pendirian Perguruan Tinggi Islam di Jakarta dan beberapa kebijakan lainnya (Zuhairini \& Dkk, 2010). Walaupun demikian, adanya kebijakan yang sedikit memberikan ruang gerak terhadap pendidikan Islam, menjadi angin segar bagi perkembangan dan perluasan pendidikan Islam di awal kemerdekaan Bangsa ini. 


\section{Perkembangan Pendidikan Islam pada Masa Orde lama}

Periode Orde Lama yang berlangsung dari tahun 1945 hingga tahun 1966. Pada periode ini kegiatan pendidikan di tanah air lebih mengarah pada pemantapan nilai-nilai nasionalisme, identitas bangsa, dan pembangunan fondasi ideologis kehidupan berbangsa dan bernegara. Tujuan utama pendidikan pada periode ini adalah nation and character building dan kendali utama penyelenggaraan pendidikan nasional dipegang oleh tokoh - tokoh nasionalis .

Pada periode ini, kurikulum ditetapkan berasaskan pancasila yang dikenal dengan "Rencana Pelajaran 1947" yang baru dilaksanakan pada tahun 1950. Kurikulum ini mengutamakan pendidikan watak, kesadaran bernegara dan bermasyarakat (Daeng Pawero, 2018). Oleh karena itulah kebijakan pemerintah terhadap pendidikan Islam lebih baik dari pada pra kemerdekaan (masa kolonial). Hal tersebut dapat dilihat dengan adanya keputusan yang dihasilkan oleh Badan Pekerja Komite Nasional Indonesia Pusat (BP-KNIP) yang mengusulkan kepada kementerian PP\&K pada tanggal 29 Desember 1945, bahwa pendidikan agama menjadi bagian dari kurikulum pendidikan nasional yang diajarkan di Sekolah Menengah Pertama (SMP). Keputusan ini merupakan langkah pertama dalam sejarah Indonesia, pasca kemerdekaan.

Pada tahun 1947, Pemerintah membentuk Majelis Pertimbangan Pengajaran Agama (MPPA) yang dipimpin oleh Ki Hajar Dewantara dari Departemen Pendidikan dan Prof. Drs. Abdullah Sigit dari Depatemen Agama, menghasilkan keputusan bahwa pendidikan agama melalui kurikulum 1947 yang berlaku sampai dengan tahun 1952 masuk ke dalam setiap jenjang pendidikan, mulai dari kurikulum Sekolah Rakyat, kurikulum SMP, dan kurikulum SMA (Susanto, 2009).

Selanjutnya, sebagaimana yang terdapat dalam Zulhandra yang dikutip oleh Ismail, bahwa pada tanggal 20 Juni 1951, dibentuk peraturan Pendidikan Agama di setiap sekolah yang merupakan hasil dari Surat Keputusan Bersama (SKB) antara Departemen Agama dan Departemen Pendidikan dan Kebudayaan, yaitu (Ismail, 2016):

a. Pendidikan agama mulai diberikan pada kelas IV Sekolah Rakyat;

b. Di lingkungan yang istimewa, pendidikan agama dapat dimulai pada kelas 1 dan jamnya dapat ditambah menurut kebutuhan tetapi tidak melebihi 4 jam seminggu dengan ketentuan bahwa mutu pengetahuan umum bagi 
sekolah-sekolah rendah itu tidak boleh dikurangi dibandingkan dengan sekolah-sekolah rendah di lingkungan lain;

c. Di setiap sekolah rendah dan sekolah lanjutan (umum dan kejuruan) diberi pendidikan agama, dengan alokasai waktu 2 jam per minggu;

d. Pendidikan agama diberikan kepada murid-murid sedikitnya 10 orang dalam satu kelas dan mendapatkan izin dari orang tua/wali;

e. Pengangkatan guru agama, biaya pendidikan agama, dan materi pendidikan agama ditanggung oleh Departemen Agama.

Kemudian pendidikan Islam menemukan eksistensinya ketika TAP MPRS No. 2 tahun 1960 menetapkan bahwa: "Pemberian pelajaran agama pada semua tingkat pendidikan, mulai dari Sekolah Dasar sampai dengan Perguruan Tinggi Negeri", di samping pengakuan bahwa "Pesantren dan Madrasah sebagai lembaga pendidikan yang otonom di bawah pembinaan Depatemen Agama" (Ismail, 2016).

Dari paparan di atas, menunjukkan bahwa Pemerintah Orde Lama sudah berupaya untuk melakukan pembenahan terhadap kebijakan pendidikan Islam, namun akibat suhu politik yang tidak kondusif, di antaranya akibat adanya pertentangan antara kelompok nasionalis, sekuler-komunis, dan Islam, hal itu berpengaruh terhadap implementasi kebijakan pendidikan Islam.

3. Perkembangan Pendidikan Islam pada Masa Orde Baru

Lengsernya Presiden Soekarno tahun 1966 menjadi awal dari masa Orde Baru (ORBA) dan dimulainya babak baru bagi bangsa Indonesia. Kebijakan pendidikan pada periode ini ditandai dengan lahirnya kurikululm 1968 yang oleh sebagian kalangan lebih bersifat politis, karena menggantikan kurikulum 1964 yang dicitrakan sebagai produk orde lama (Daeng Pawero, 2018). Pada tahun ini pula muncul angkatan baru yang dikenal dengan sebutan angkatan 66. Pada masa pemerintahan ini sangat identik dengan slogan atau ideologi pembangunan. Sehingga semua kebijakannya, termasuk dalam kebijakan pendidikan selalu di arahkan kepada gerak pembangunan. Dalam mengejewantahkan kebijakan, pemerintah Orde Baru yang dipimpin oleh Presiden Soeharto disusun dalam bentuk tahapan-tahapan pembangunan yang disebut dengan REPELITA (Rencana Pembangunan Limat Tahun) dengan diawalinya REPELITA I pada tanggal 1 April 1969. 
Pembangunan Sumber Daya Manusia (SDM) adalah tujuan akhir dari pembangunan nasional. Maka dari itu tujuan pendidikan nasional adalah terbentuknya manusia Indonesia yang unggul, paripurna memilki ilmu pengetahuan dan bertaqwa kepada Tuhan Yang Maha Esa serta dapat mengahadapi tantangan yang penuh dengan persaingan global dalam berbagai bidang kehidupan politik, ekonomi, sosial dan budaya, baik pada tingkat nasional maupun internasional.

Dalam implementasi pembangunan nasional yang menitikberatkan kepada pembangunan SDM, ternyata masih mengalami hambatan dengan adanya kebijakan sentralistik dalam pelaksanaan kurikulum pendidikan, sehingga hal itu menyebabkan terbelenggunya kreativitas manusia Indonesia dalam mengembangkan pendidikan.

Banyaknya kritikan dari berbagai pihak, menyebabkan pemerintah berusaha untuk memperbaiki kebijakan (politik) pendidikan yang lebih berpihak kepada masyarakat. Undang-Undang Sistem Pendidikan Nasional (UUSPN) 1989 sebagai landasan politik dalam pendidikan nasional menjadikan seluruh sistem pendidikan untuk menempatkan diri sebagai subsistem dari sistem pendidikan nasional, termasuk di dalamnya adalah pendidikan Islam .

Pada periode ini, kebijakan sistem pendidikan nasional didasarkan pada Tap MPRS No.27, pasal 1 tanggal 5 Juli 1966; yang menetapkan bahwa "Agama, pendidikan dan kebudayaan adalah unsur mutlak dalam Nation and Character Building", dan sekaligus menetapkan bahwa "Pendidikan agama menjadi mata pelajaran pokok dan wajib diikuti oleh setiap murid/mahasiswa sesuai dengan agamanya masing-masing". Pada pasal 4 TAP MPRS ini menyebutkan bahwa isi pendidikan untuk mencapai dasar dan tujuan pendidikan adalah:

a. Mempertinggi mental, moral, budi pekerti dan memperkuat keyakinan beragama.

b. Mempertinggi kecerdasan dan keterampilan.

c. Membina dan mengembangkan fisik yang kuat dan sehat.

Kemudian dengan adanya hasil sidang Majelis Perwakilan Rakyak (MPR) dalam menyusun Garis-garis Besar Haluan Negara pada tahun 1973-1978 dan 1983 sebagimana berikut (Zuhairini \& Dkk, 2010):

Bahwa bangsa dan pemerintah Indonesia bercita-cita menuju kepada apa yang terkandung dalam Pembukaan UUD 1945. Pembangunan Nasional 
dilaksanakan dalam rangka pembangunan manusia Indonesia seutuhnya. Hal ini berarti adanya keserasian, keseimbangan, dan keselarasan antara pembangunan bidang jasmani dan rohani, antara bidang material dan spritual, antara bekal keduniaan dan ingin berhubungan dengan Tuhan Yang Maha Esa, dengan sesama manusia dan dengan lingkungan hidupnya secara seimbang. Pembangunan seperti tersebut di atas menjadi pangkal tolak pembangunan bidang agama.

Untuk selanjutnya, rumusan tersebut semakin sempurna dengan lahirnya UU RI No. 2 tahun 1989 tentang Sistem Pendidikan Nasional, pada bab I pasal 11 ayat 7 menyebutkan bahwa pendidikan keagamaan merupakan pendidikan yang yang bertujuan untuk mempersiapkan peserta didik agar dapat menjalankan peranan yang menuntut penguasaan pengetahuan khususnya tentang ajaran agama yang bersangkutan. Dengan berlakunya UUSPN tersebut menjadikan terintegrasinya pendidikan Islam ke dalam sistem pendidikan nasional serta hal itu menyebabkan adanya peluang dan kesempatan bagi pendidikan Islam untuk selalu berkembang secara dinamis (A. M. D. Pawero \& Dkk, 2019b).

\section{Perkembangan Pendidikan Islam pada Masa Reformasi}

Berawal dari peristiwa moneter yang melanda perekonomian bangsa Indonesia pada tahun 1998, menjadi akhir dari kekuasaan Soeharto. Zaman yang disebut dengan istilah masa reformasi ini menyebabkan terbukanya ruang kebebasan berdemokrasi dalam segala aspek yang selama 32 tahun terpasung.

Gerakan reformasi di Indonesia menuntut diterapkannya prinsip demokrasi, desentralisasi, keadilan, dan menjunjung tinggi hak asasi manusia dalam kehidupan berbangsa dan bernegara. Dalam hubungannya dengan pendidikan, prinsip-prinsip tersebut akan memberikan dampak yang mendasar pada kandungan, proses, manajemen, dan teknologi berkembang pesat dan memunculkan tuntutan baru dalam seluruh aspek kehidupan, termasuk sistem pendidikan nasional.

Semenjak istilah reformasi didengungkan pada tahun 1998, maka semenjak itu pulalah banyak kalangan dari pemerhati pendidikan yang mengkritisi UUSPN nomor 2 tahun 1989. Mereka menganggap undang-undang ini sudah tidak relevan, sehingga perlu adanya pergantian undang-undang yang mengatur pendidikan di Indonesia, temasuk pendidikan Islam.

Pada masa reformasi ini, pergantian Undang-Undang nomor 2 tahun 1989 ke Undang-Undang nomor 20 tahun 2003 tentang Sistem Pendidikan Nasional, khususnya pada pasal 12 ayat 1 (a) yang berbunyi "setiap peserta didik pada setiap 
lembaga/ satuan pendidikan berhak mendapatkan pedidikan agama sesuai dengan agama yang dianutnya dan diajarkan oleh pendidik agama yang seagama", adalah spirit baru bagi perkembangan pendidikan nasional, khususnya bagi perkembangan pendidikan Islam di Indonesia.

Undang-undang nomor 20 tahun 2003 di atas lebih bermakna dan aplikatif, ketika pada tahun 2013 tercetus sebuah konsep kurikulum, yang dikenal dengan nama kurikulum 2013 (KURTILAS) yang merupakan pengembangan kurikulum sebelumnya yaitu, Kurikulum Berbasis Kompetensi (2004) dan Kurikulum Tingkat Satuan Pendidikan (2006). Di mana, pada tahun yang sama, terbit Peraturan Menteri Pendidikan dan Kebudayaan Nomor 64 Tahun 2013 Tentang Standar Isi Pendidikan Dasar dan Menengah yang menguraikan tentang Kompetensi Inti, khususnya pada KI 1 (Sikap Spritual) dan KI 2 (Sikap Sosial) yang berhubungan dengan nilai-nilai pendidikan Islam, yakni habl min Allah dan habl mi al-nas.

Dinamika kebijakan (politik) pendidikan Islam pada masa reformasi yang sangat menguntungkan umat Islam sebenarnya tidak lepas dari peran pemegang kebijakan dan anggota Dewan Perwakilan Rakyat Republik Indonesia (DPRRI) yang peduli terhadap pendidikan Islam, khususnya mereka yang berasal dari partai yang berbasis keagamaan (Islam).

\section{Simpulan}

Dari paparan di atas dapat disimpulkan bahwa:

1. Politik pendidikan Islam merupakan seluruh kebijakan yang tetapkan oleh penguasa dari suatu pemerintahan yang terkait dengan keberlangsungan proses pendidikan Islam, di mana ia sebagai bagian dari sistem pendidikan nasional.

2. Terjadinya relasi politik dan pendidikan Islam di Indonesia sebenarnya telah dimulai sejak masa pra kemerdekaan bahkan jauh sebelum itu. Jika melihat dinamika politik pendidikan Islam mulai pra kemerdekaan sampai dengan masa reformasi, kebijakan pemerintah terus berkembang pada arah yang positif. Yaitu pada upaya menciptakan keserasian, keseimbangan, dan keselarasan antara pembangunan bidang jasmani dan rohani, antara bidang material dan spritual, serta menciptakan hubungan harmonis antara manusia dengan lingkungan hidupnya. 


\section{Referensi}

Achmadi. (2002). Islam Sebagai Paradigma Ilmu Pendidikan. Yogyakarta: Aditya media.

Bakri, M. (2010). Formulasi dan Implemetasi Kebijakan Pendidikan Islam; Analisis Kritis Terhadap Proses Pembelajaran. Surabaya: Visipress Media.

Budihardjo, M. (2001). Dasar-dasar Ilmu Politik. Jakarta: Gramedia.

Daeng Pawero, A. M. V. (2018). Analisis Kritis Kebijakan Kurikulum Antara KBK, KTSP, dan K-13. Jurnal Ilmiah lqra', 12(1), 42. https://doi.org/10.30984/jii.v12i1.889

Ellong, T. D. E., \& Pawero, A. M. D. (2018). Islamic Education Management for Millenial Generation; Quality and Competitivaness. In The 1st Annual Conference on Islamic Education Management (ACIEM). Yogyakarta: Fakultas Ilmu Tarbiyah dan Keguruan UIN Sunan Kalijaga.

Ismail. (2016). Politik Pendidikan Islam Orde Lama 1945-1965 (Study Kebijakan Pemerintah dalam Penyelenggaraan Pendidikan Islam). Journal of Social Community STAI NATA Sampang, 1(1).

Jalaluddin. (2004). Filsafat Pendidikan Islam. Jakarta: Raja Grafindo Persada.

Marimba, A. D. (2009). Pengantar Filsafat Pendidikan. Bandung: Al-Ma'arif.

Muhmidayeli. (2011). Filsafat Pendidikan. Bandung: Refika Aditama.

Nata, A. (2001). Sejarah Pertumbuhan dan Perkembangnan Lembaga-Lembaga Pendidikan Islam di Indonesia. Jakarta: PT Grasindo.

Nata, A., \& Dkk. (2004). Sejarah Pendidikan Islam. Jakarta: Raja Grafindo Persada.

Oxford. (2011). Learner's Pocket Dictionary. New York: Oxford University Press.

Pawero, A. M. (2017). Analisis Kritis Kebijakan Standar Kompetensi Lulusan (SKL) Dan Standar Isi Kurikulum Pendidikan Agama Islam. Journal of Islamic Education Policy, 2(2). https://doi.org/10.30984/j.v2i2.700

Pawero, A. M. D., \& Dkk. (2019a). Contemporary Issues on Religion and Multiculturalism. Manado: Cv. Istana Agency.

Pawero, A. M. D., \& Dkk. (2019b). The Scientific Paradigm of Islamic Education Management. In Procceding The 2nd Annual Conference on Islamic Education Management (Vol. 53, pp. 1689-1699). https://doi.org/10.1017/CBO9781107415324.004

Rifai, M. (2011). Sejarah Pendidikan Nasional Dari Masa Klasik Hingga Modern. Yogyakarta: Ar Ruz Media.

Sirozi, M. (2010). Politik Pendidikan. Jakarta: PT. Raja Grafindo Persada. 
Suryanegara, A. M. (2012). Api Sejarah. Bandung: PT Grasindo.

Susanto, E. (2009). Pendidikan Agama dalam Sistem Pendidikan di Indonesia; Survey Historis Era Pemerintahan Soekarno. Jurnal Pendidikan Islam Prodi PAI Jurusan Tarbiyah STAIN Pamekasan, 4(1).

Tim Redaksi. (2011). Kamus Besar Bahasa Indonesia. Jakarta: PT. Gramedia Pustaka Utama.

Zuhairini, \& Dkk. (2010). Sejarah Pendidikan Islam. Jakarta: Bumi Aksara. 